\title{
Self-Efficacy as Mediator: The Impact of Entrepreneur Education on Entrepreneur Intention
}

\author{
Rr. Fosa Sarassina* \\ *University of Gadjah Mada \\ Economics and Business Department Vocational school \\ Jl. Prof. Drs. Notonagoro, Bulaksumur, Sleman, Yogyakarta 55281, Indonesia \\ E-mail: fosa.sarassina@ugm.ac.id
}

\begin{abstract}
The literature review shows inconsistent results of the relationship between entrepreneurial education with entrepreneurial intention and recommends the investigation of the role of self-efficacy as a mediator between the two constructs. This study aims to meet that purpose. From the response of 241 students in Jogjakarta, which was analyzed using structural equation modeling (SEM), it is concluded that self-efficacy mediates the relationship. This finding signifies the role of entrepreneurship education as it builds self-efficacy to become an entrepreneur, which in turn increases the intention to become one.
\end{abstract}

Keywords: Entrepreneur intention, self-efficacy, entrepreneur education, mediating test, mediator

\begin{abstract}
Abstrak
Tinjauan literatur menunjukkan hasil yang tidak konsisten dari hubungan antara pendidikan kewirausahaan dengan niat kewirausahaan dan merekomendasikan penyelidikan peran efikasi diri sebagai mediator antara dua konstruksi. Penelitian ini bertujuan untuk memenuhi tujuan itu. Dari respons 241 siswa di Yogyakarta, yang dianalisis dengan menggunakan pemodelan persamaan struktural (SEM), disimpulkan bahwa self-efficacy memediasi hubungan. Temuan ini menandakan peran pendidikan kewirausahaan karena membangun self-efficacy untuk menjadi wirausaha, yang pada gilirannya meningkatkan niat untuk menjadi wirausaha.
\end{abstract}

Kata Kunci: Niat wirausaha, efikasi diri, pendidikan wirausaha, tes mediasi, mediator

\section{Introduction}

The entrepreneurial intention had been studied extensively and become the core of entrepreneurial creation [1] [2] [3] [4] [5] [6] [7], its role as the main antecedents of entrepreneurial.

Self-behavior is rarely replaced by other constructs and its ability to explain the variance of entrepreneurial behavior is high and therefore become one of the most preferred main topics of entrepreneurial research [8] [9].

In Indonesia, the studies of entrepreneurship intention had been focused on entrepreneurial creation among the University students mainly because they are considered to graduate soon and are going to decide on employment, something that is perceived to be decided together with the decision to become entrepreneurs [10].

The intention to become entrepreneurs are shaped by various factors, among others are personality [11], Self-efficacy [12] [13], attitude [2] [9] [14], subjective norm [3] [9] [14], and entrepreneur education [15] [16] [17], see table 1 for the detail of studies reviewed. Among many factors that influence entrepreneurial intention, self-efficacy is considered as the most influencing factor [18] [19]. Considering that self-efficacy is highly influenced by skill and knowledge of entrepreneurship which shaped by entrepreneur education [15] [17], then a research studying the influence of entrepreneur education to self-efficacy becomes paramount.

In Indonesia where this study takes place, entrepreneurial education is considered an important part of curricula. Many universities provide entrepreneur class as an integral part of curricula and obliged the university students to study entrepreneurship trough, entrepreneurship class. Through these classes, the universities wish to increase the entrepreneurial intention of their students and hopefully, realizing their intention to become an entrepreneur [20]. Considering the importance of entrepreneur education, many studies have investigated the influence of entrepreneur education on student intention in Indonesia [21] [22]. These studies, along with some other country's studies such as China [17], Japan, Spain and USA [7], and Pakistan [23], have tried to investigate the influence of entrepreneur education and self-efficacy on student entrepreneur 
intention. These studies, state that entrepreneur education influences self-efficacy and self-efficacy influence entrepreneur intention. Those studies, however, did not investigate the possibility of mediating the relationship of self-efficacy between entrepreneur education and entrepreneur intention.

In sum, we have developed a framework to investigate the mediating relationship (see figure 1).

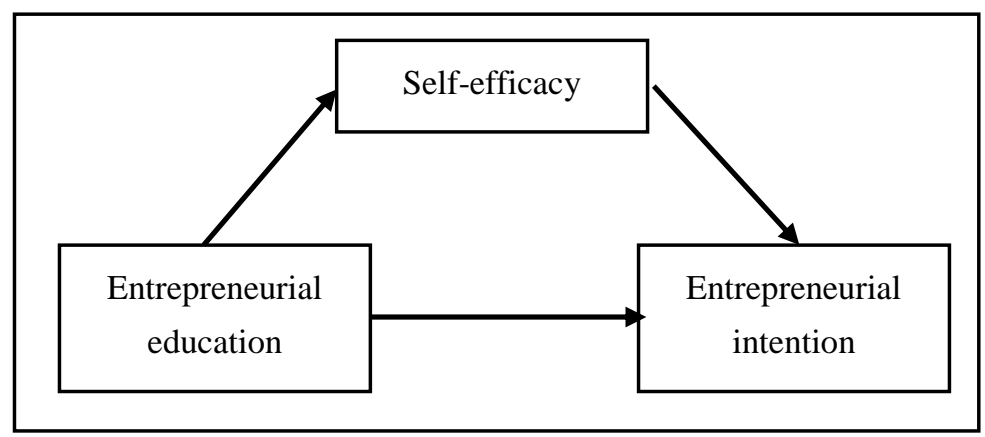

Figure 1: Proposed Model

The cognitive theory had been vastly used in studying entrepreneurship with entrepreneurial education as the central point for the antecedent of entrepreneurial behavior. The most commonly used theories are the Theory of Planned Behavior which proposes attitude, self-efficacy, and subjective norm as an antecedent of entrepreneurial intention. Other model of entrepreneurial intention that have gained its popularity is Shapero Entrepreneurial Exposure or SEE model. Both models had been compared by Krueger [8] and through that study, self-efficacy, which exists both in the theories, is considered as an antecedent of entrepreneurial intention. Besides that study, several studies have investigated the role of entrepreneurial education as shown in table 1 .

TABLE I. FACTORS INFLUENCING ENTREPRENEURIAL INTENTION

\begin{tabular}{|c|c|c|c|c|c|}
\hline Author, year & Country & Directly influencing Factors & Findings & $\begin{array}{l}\text { Analysis } \\
\text { Method }\end{array}$ & $\begin{array}{c}\text { Mediating } \\
\text { test }\end{array}$ \\
\hline Carda et al 2016 & $\begin{array}{l}\text { Japan, } \\
\text { Spain, USA }\end{array}$ & Entrepreneurship education & Entrepreneurship education + & SEM & No \\
\hline Sarassina, 2016 & Indonesia & Self-efficacy & Self-efficacy insignificant & SEM & yes \\
\hline Katono 2012 & Africa & $\begin{array}{l}\text { Self-efficacy, attitude, } \\
\text { subjective norm }\end{array}$ & $\begin{array}{l}\text { Self-efficacy }+ \text {, attitude }+ \text {, subjective } \\
\text { norm }+\end{array}$ & SEM & No \\
\hline Zhang 2014 & China & $\begin{array}{l}\text { Self-efficacy, perceived } \\
\text { desirability, entrepreneurship } \\
\text { education }\end{array}$ & $\begin{array}{l}\text { Self-efficacy }+ \text {, perceived desirability } \\
+, \text { entrepreneurship education }+\end{array}$ & SEM & No \\
\hline Saeed et al 2013 & Pakistan & Entrepreneurial intention & $\begin{array}{l}\text { Entrepreneurial education }+ \text { to } \\
\text { Self-efficacy and } \mathrm{SE}+\text { to intention, no } \\
\text { mediation analysis }\end{array}$ & SEM & No \\
\hline Sihombing 2012 & Indonesia & Attitude, Subjective Norm & Attitude,+ Subjective Norm +, SE + & SEM & No \\
\hline Lestari 2012 & Indonesia & $\begin{array}{l}\text { Attitude, Subjective Norm, } \\
\text { Self-efficacy, } \\
\text { entrepreneurship education }\end{array}$ & $\begin{array}{l}\text { Attitude, Subjective Norm, } \\
\text { Self-efficacy, entrepreneurship } \\
\text { education, entrepreneurship education } \\
\text { is considered as attitude, Subjective } \\
\text { norm and self-efficacy and the result } \\
\text { all + sig }\end{array}$ & Correlation & No \\
\hline $\begin{array}{l}\text { Moriano et al } \\
2012\end{array}$ & $\begin{array}{l}\text { Poland, } \\
\text { Ireland, } \\
\text { Netherland }\end{array}$ & $\begin{array}{l}\text { Attitude, subjective norm and } \\
\text { Self efficacy }\end{array}$ & $\begin{array}{l}\text { Self-efficacy }+ \text {, attitude }+ \text {, subjective } \\
\text { norm }+\end{array}$ & SEM & No \\
\hline Linan 2009 & Finland & $\begin{array}{l}\text { Self-efficacy, attitude, } \\
\text { subjective norm }\end{array}$ & $\begin{array}{l}\text { Self-efficacy }+ \text {, attitude }+ \text {, subjective } \\
\text { norm }+\end{array}$ & SEM & No \\
\hline Krueger 1993 & USA & $\begin{array}{l}\text { Self-efficacy, perceived } \\
\text { desirability, propensity to act, } \\
\text { Subjective Norm }\end{array}$ & $\begin{array}{l}\text { Self-efficacy }+ \text {, perceived desirability } \\
+, \text { propensity to act }+ \text {, Subjective } \\
\text { Norm }+\end{array}$ & SEM & No \\
\hline $\begin{array}{l}\text { Wirandana, } \\
2017\end{array}$ & Indonesia & $\begin{array}{l}\text { Self-efficacy, } \\
\text { Entrepreneurship Education }\end{array}$ & $\begin{array}{l}\text { Attitude, SN and SE Self efficacy } \\
\text { significant to entrepreneur intention, } \\
\text { entrepreneurship education sig + to } \\
\text { attitude only }\end{array}$ & SEM & No \\
\hline $\begin{array}{l}\text { Nowinski et al, } \\
2017\end{array}$ & $\begin{array}{l}\text { Czech } \\
\text { Republic, } \\
\text { Slovakia, } \\
\text { Poland, } \\
\text { Hungary }\end{array}$ & $\begin{array}{l}\text { Self-efficacy, while SE is } \\
\text { influenced by } \\
\text { entrepreneurship education }\end{array}$ & $\begin{array}{l}\text { Self-efficacy sig }+ \text { to intention and } \\
\text { entrepreneurship education is } \\
\text { significant to SE }\end{array}$ & SEM & Yes \\
\hline
\end{tabular}


Based on table 1, it can be concluded that Attitude, Subjective Norm and Perceived Behavioral Control (self-efficacy) and entrepreneur education are the most common variables, where two types of research exist: entrepreneur education is investigated as a direct antecedent of entrepreneurship intention [17] [7] or as an antecedent of self-efficacy [20]. The latter type of research, which studies self-efficacy as a mediator between entrepreneurship education and entrepreneurial intention, however, is still rare and the study on mediator relationship of self-efficacy is still understudied [20], therefore this study developed hypothesizes as follows:

H1: Self-efficacy positively affects entrepreneurial education

$\mathrm{H} 2$ : Entrepreneurial education positively affects self-efficacy and

H3: Self-efficacy mediates the relationship between entrepreneurial education and entrepreneur intention.

\section{Methods}

This study employs systematic random sampling, where there was the list of universities in Jogjakarta, Indonesia, and the second chosen university on the list is selected, therefore, the University researched are Universitas Gadjah Mada, Universitas Islam Indonesia, and Universitas Islam Negeri Jogjakarta. The questioners were distributed to 600 students through the mall intercept method, 300 responded and only 250 had filled in without missing value. Therefore, the response rate is $40.01 \%$.

The item used in the questionnaire are questions that had been used in previous research with high reliability and validity. The details of the items used are explained as follows.

For the dependent variable, the entrepreneurial intention is using the following questions: I am ready to do anything to become an entrepreneur (EIN1), I want to build a career as an entrepreneur (EIN2), I will do anything to become an entrepreneur (EIN3), I am willing to build my own company (EIN4), I am sure I will have my own company (EIN5). The reliability of the instrument is high, 0.962 [13].

For independent variable, self-efficacy, the questions were as follows: Starting a company is an easy thing for me (SE1)- I am ready to build a company (SE2)- I understand what to do to start my own company (SE3)- I know how to start a project (SE4)- I am sure I will be a successful entrepreneur (SE5). This instrument has a Cronbach alpha of 0,936, which shows high reliability [13].

Entrepreneurial education items are as follows: The university where I study: Develop my entrepreneurial skill (EE1)-Equip me with enough knowledge to become an entrepreneur (EE2)-support me to develop creative ideas to become an entrepreneur (EE3). This instrument had been used by Carda and the reliability is high, the Cronbach alpha is 0.847 [7].

\section{Findings and Discussion}

Unidimensional test had been performed. The result shows that all loading factors have exceeded the minimum value of 0.5 . An indicator is considered as having a convergent validity if its loading factor exceeds 0.5 . The loadings are depicted in Picture IV 1. The loading factors. From Figure IV.1, all factor loadings have exceeded the required number, thus reaching its convergent validity. After the unidimensional test, the next evaluation is examining the outer model or measurement model; and reading the inner model or relationship among constructs.

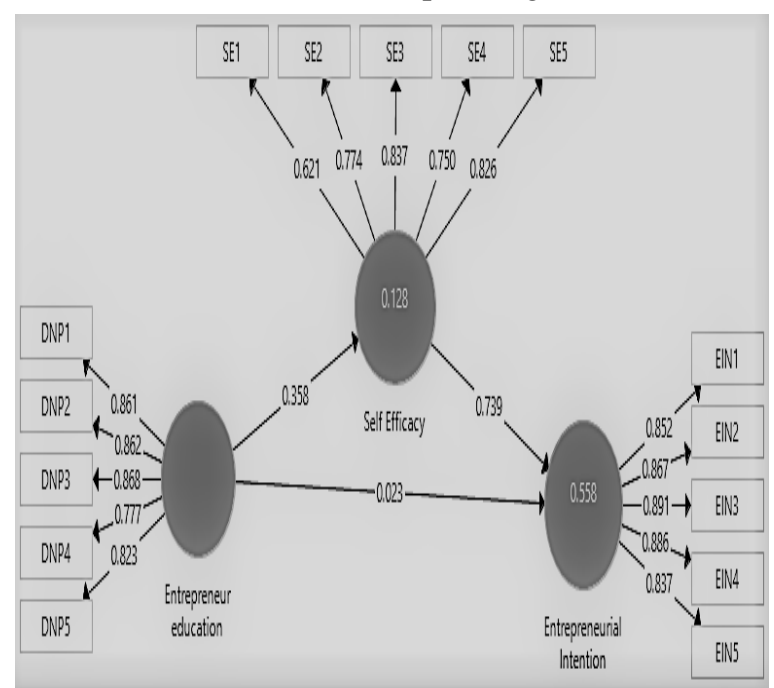

Figure 2: Algorithm result

To examine the outer model, two things are being evaluated: discriminant validity and composite reliability. The composite reliability and discriminant validity are depicted in table IV. 1 Based on the table, it is concluded that the construct is reliable as the Composite reliability is above 0.6 and it is also considered valid, as all the construct's AVE is above 0.5 .

TABLE 2. COMPOSITE RELIABILITy AND AVERAGE VARIANCE

\begin{tabular}{lll}
\multicolumn{3}{c}{ EXTRACTED (AVE) } \\
\hline Construct & $\begin{array}{l}\text { Composite } \\
\text { Reliability }\end{array}$ & AVE \\
\hline $\begin{array}{l}\text { Entrepreneurial } \\
\text { Education }\end{array}$ & 0.922 & 0.704 \\
$\begin{array}{l}\text { Entrepreneurial } \\
\text { Intention }\end{array}$ & 0.938 & 0.752 \\
Self-Efficacy & 0.875 & 0.586 \\
\hline
\end{tabular}

After reaching the reliability and validity of the constructs, then the next evaluation of the model is the inner model, as depicted in Figure 2 Algorithm result and Figure 3 Bootstrapping results. 


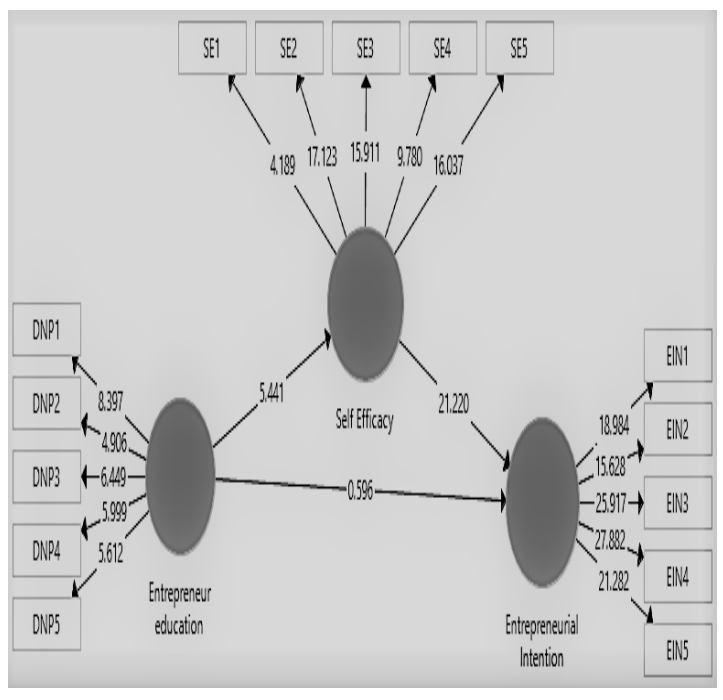

Figure 3: Bootstrapping result

The algorithm and bootstrapping result are used to evaluate the relationships among constructs. The $\mathrm{R}$ square shows that the model is able to explain that self-efficacy explains $55.8 \%$ of entrepreneurial intention, a moderate result. This result means that intention to become an entrepreneur is largely explained by self-efficacy which is explained by $12,8 \%$ entrepreneur education. After evaluating R2, the next evaluation is the path coefficient, which shows that all paths are significant with the result of 5.441 for entrepreneur education to self-efficacy and 21.220 for the path of self-efficacy to entrepreneurial intention, while it is insignificant for the direct path between entrepreneur education to entrepreneur intention. This means, self-efficacy fully mediates the relationship between entrepreneurial education to entrepreneurial intention.

\section{Conclusions}

The finding shows that the relationship between entrepreneur education and entrepreneur intention is mediated by self-efficacy. This finding means that in order to increase the likelihood of a student being an entrepreneur, the intervention such as entrepreneur education can be used to increase self-efficacy of the student and in turn, the willingness to become an entrepreneur. These findings support the previous finding in the Czech Republic, Hungary, Slovakia, and Poland and contrary to the previous finding of research in Indonesia which finds that the attitude that mediates the relationship. Further study is required with a larger number of sample and more cross-country sample is needed.

\section{References}

A. Azhar, A., Javaid, A., Rehman, M., \& Hyder, A. (2010). Entrepreneurial Intentions among Business Students in. Journal of Business Systems, Governance and Ethics, 5(2), 13-21. http://doi.org/10.1080/1463244011009463
B. Liñán, F., \& Chen, Y. (2006). Testing the entrepreneurial intention model on a two-country sample. Documents de treball d'economia de l'empresa (Vol. 06/7). Spain.

C. Liñán, F., Urbano, D., \& Guerrero, M. (2011). Regional variations in entrepreneurial cognitions: Start-up intentions of university students in Spain. Entrepreneurship \& Regional Development, 23(3-4), 187-215. http://doi.org/10.1080/08985620903233929

D. Mitchell, R. K., Smith, J. B., Morse, E. A., Seawright, K. W., Peredo, A. M., \& Mckenzie, B. (2002). Are Entrepreneurial Cognitions Universal? Assessing Entrepreneurial Cognitions Across Cultures. Entrepreneurship: Theory \& Practice, 26(4), 9. http://doi.org/Article

E. Morandin, G., Bergami, M., \& Bagozzi, R. P. (2006). The hierarchical cognitive structure of entrepreneur motivation toward private equity financing. Venture Capital, 8(3), 253-271. http://doi.org/10.1080/13691060600748546

F. Sarassina, F., Nik Mat, N., \& Suryasaputra, R. (2015). The validation of self-efficacy instrument for franchisee entrepreneur. Australian Journal of Basic and Applied Science, 9(22), 108-113.

G. Zurriaga-carda, A., Kageyama, K., \& Akai, K. (2016). Effects of Risk Attitude, Entrepreneurship Education and Self-Efficacy on Entrepreneurial Intentions: A Structure Equation Model Approach to Entrepreneurship, (Jackson 1994), 1424-1433

H. Krueger, N. F., M D Jr., R., \& Carsrud, A. L. (2000). Competing models of entrepreneurial intentions. Journal of Business Venturing, 15(98), 411-432.

I. Moriano, J. A., Gorgievski, M., Laguna, M., Stephan, U., \& Zarafshani, K. (2012). A cross-cultural approach to understanding entrepreneurial intention. Journal of Career Development, 39(2), 162-185. http://doi.org/10.1177/0894845310384481

J. Kaufmann, P. J., \& Dant, R. P. (1998). Franchising and the domain of entrepreneurship research. Journal of Business Venturing, 14(1), 5-16. http://doi.org/10.1016/S0883-9026(97)00095-5

K. Praditbatuga, P. (2007). Reaching the decision to purchase a franchise in Thailand. University of South Australia. Retrieved from Available from ProQuest Dissertations and Theses database

L. Katono, I. W., Heintze, A., \& Byabashaija, W. (2010). Environmental factors and graduate start up in Uganda. In Conference on Entrepreneurship in Africa.

M. Liñán, F., \& Chen, Y. (2009). Development and 
cross-cultural application of a specific instrument to measure entrepreneurial intentions. Entrepreneurship Theory and Practice, 593-617.

N. Sihombing, S. O. (2012). Comparing entrepreneurship intention: A multigroup structural equation modeling approach. International Research Journal of Business Studies, 5(1)

O. Nowiński, W., Haddoud, M. Y., Lančarič, D., \& Czeglédi, C. (2017). Studies in Higher Education The impact of entrepreneurship education, entrepreneurial self-efficacy and gender on entrepreneurial intentions of university students in the Visegrad countries, 5079(August). http://doi.org/10.1080/03075079.2017.1365359

P. Piperopoulos, P., \& Dimov, D. (2015). Burst Bubbles or Build Steam? Entrepreneurship Education, Entrepreneurial Self-Efficacy, and Entrepreneurial Intentions. Journal of Small Business Management, 53(4), 970-985.

Q. Zhang, Y., Duysters, G., \& Cloodt, M. (2014). The role of entrepreneurship education as a predictor of university students' entrepreneurial intention, 623-641.

http://doi.org/10.1007/s11365-012-0246-Z

R. Sarassina, R. (2016). THE RELATIONSHIP BETWEEN SELF EFFICACY AND GOAL REALIZATION IN INDONESIA FOODSERVICE INDUSTRY. Universiti Utara Malaysia. Retrieved from http://etd.uum.edu.my/6311/

S. Setiabudi, J. (2009). The power of kepepet. Jakarta: Gramedia.

T. Wirandana, E., Pamulang, U., Hidayati, S., \& Pamulang, U. (2017). PENGARUH PENDIDIKAN KEWIRAUSAHAAN TERHADAP NIAT, (December).

U. Lestari, R. B., \& Wijaya, T. (2012). Pengaruh Pendidikan Kewirausahaan Terhadap Minat Berwirausaha Mahasiswa. Jurnal Ilmiah STIE MDP, 1(2), 112-119.

V. Marganingsih, T. (2013). Solidarity: Journal of Education, Society and Culture MENGEMBANGKAN JIWA KEWIRAUSAHAAN SISWA KELAS XI DI SMK, 2(2), 120-128.

W. Saeed, S., Yousafzai, S. Y., Yani-De-Soriano, M., \& Muffatto, M. (2015). The Role of Perceived University Support in the Formation of Students' Entrepreneurial Intention. Journal of Small Business Management, 53(4), 1127-1145. 